\title{
Production of Activated Carbon from Moldy Damaged Tamarind-Pod
}

\author{
Piyarut Moonsri ${ }^{1, a^{*}}$, Wilaiporn Pongpian ${ }^{1, b}$, Kristiya Moonsri ${ }^{2, c}$ \\ ${ }^{1}$ Department of Chemistry, Faculty of Science and Technology, Phetchabun Rajabhat University, \\ Phetchabun 67000, Thailand. \\ ${ }^{2}$ Department of Management, Faculty of Social Science, Phetchabun Rajabhat University, \\ Phetchabun 67000, Thailand. \\ a*piyarutto@hotmail.com, batom2141@gmail.com, kristiya_ripb@hotmail.com
}

Keywords: activated carbon, tamarind pod, pyrolysis

\begin{abstract}
This research studied production of activated carbon (AC) derived from tamarind pods damaged by mold. Folk wisdom kiln which manufactured from an oil tank size of $200 \mathrm{~L}$ was used for pyrolysis and carbonization of tamarind pod derived from sweet and sour tamarinds. The AC was produced by using chemical activation and thermal activation at the optimal condition. Then the physical and chemical properties of the AC were investigated. From the study, it was found that optimal condition for charcoal carbonization of the tamarind pod was $400{ }^{0} \mathrm{C}$ for $4 \mathrm{hrs}$. The optimal condition for thermal activation was $600{ }^{0} \mathrm{C}$ for $1-2 \mathrm{hrs}$. The phosphoric acid $\left(\mathrm{H}_{3} \mathrm{PO}_{4}\right)$ showed higher effectiveness for activation than distillation water $\left(\mathrm{H}_{2} \mathrm{O}\right)$, potassium hydroxide $(\mathrm{KOH})$ and zinc chloride $\left(\mathrm{ZnCl}_{2}\right)$. The produced $\mathrm{AC}$ has specific surface area of $851.58-910.31 \mathrm{~m}^{2} / \mathrm{g}(\mathrm{BET}$ Theory), a pore volume of $2.24-2.32 \mathrm{~cm}^{3} / \mathrm{g}$ with an average pore radius of 50.90 to $52.53 \AA$, iodine number of $613.9-654.8 \mathrm{mg} / \mathrm{g}$, phenols adsorption of $61.7-83.1 \%$ and apparent density $0.4528 \mathrm{~g} / \mathrm{cm}^{3}$. The results from proximate analysis shown that the AC has the moisture content of $6.81-7.54 \%$, the ash content of $6.58-7.31 \%$, the volatile matter of $38.26-40.12 \%$ and the fixed carbon of 52.57 $55.16 \%$. The performance of the AC for acetic acid adsorption according to the Langmuir and Freundlich isotherm exhibited a monolayer adsorption isotherm and the AC adsorbed the acetic acid well and strength. Therefore the produced AC can be further used for filter material in small water treatment.
\end{abstract}

\section{Introduction}

Activated carbons (AC) are carbonaceous materials that can be used as an absorbent due to its capacity for adsorption [1]. These materials are characterized by their extraordinary large specific surface areas, well-developed porosity and tunable surface-containing functional groups [2-3]. Important applications relate to the AC surface properties, it has been using as adsorbents materials for removal of taste, color, odor, and undesirable organic and chemicals impurities in the waste water treatment from domestic and industrial [4-6]. In addition, it can be used as adsorbents materials for pollution treatment and some industrials processing such as sugar industry and beverage industry [7-9]. The AC production with an inexpensive cost is the challenges in commercial manufacturing. The using of inexpensive raw materials is one of the main factors to consider for both of application used and commercial manufacturing. Generally, the raw materials for the production of AC are those with high carbon but low inorganic contents materials such as wood, lignite, peat and coal [7]. In addition, a lot of agricultural waste and by product have successfully converted to AC for example macadamia nutshell, paper mill sludge [10-13]. In Phetchabun Province, Thailand, there are potential raw materials resources from agricultural for the production of the activated carbon. In this research, agricultural waste of moldy damaged tamarind pod which released from local sweet tamarind orchards was used to produce an activated carbon due to the availability and inexpensive material with high carbon and low inorganic content. 


\section{Experimental}

Materials. The moldy damaged tamarind pods were collected from tamarind orchards (both of sweet tamarind pod and sour tamarind pod) in Phetchabun Province. Tamarind pod charcoal was prepared by using the folk wisdom kiln volume in pyrolysis process of the moldy damaged tamarind pod at charcoal carbonization condition of $400{ }^{0} \mathrm{C}$ for $4 \mathrm{hrs}$. After that the charcoal was crushed by ball mild machine in to a small granular and sieved to mesh size 8-14. All chemicals were of reagent grade.

Activated carbon production. The AC from tamarind pod was prepared by using phosphoric acid $\left(\mathrm{H}_{3} \mathrm{PO}_{4}\right)$, Potassium hydroxide $(\mathrm{KOH})$, and Zinc chloride $\left(\mathrm{ZnCl}_{2}\right)$ compared with distillation water in the charcoal activation. The test samples were divided into four portions; the first part mixed with $60 \% \mathrm{wt} / \mathrm{v}$ of $\mathrm{H}_{3} \mathrm{PO}_{4}\left(500 \mathrm{~g}\right.$ of sample $+500 \mathrm{~mL}$ of $\left.\mathrm{H}_{3} \mathrm{PO}_{4}\right)$, the second part mixed with $60 \% \mathrm{wt} / \mathrm{v}$ of $\mathrm{KOH}(500 \mathrm{~g}$ of sample $+500 \mathrm{~mL}$ of $\mathrm{KOH})$, the third part mixed with $60 \% \mathrm{wt} / \mathrm{v}$ of $\mathrm{ZnCl}_{2}\left(500 \mathrm{~g}\right.$ of sample $+500 \mathrm{~mL}$ of $\left.\mathrm{ZnCl}_{2}\right)$, and the fourth part mixed with distillation water ( $500 \mathrm{~g}$ of sample $+500 \mathrm{~mL}$ of $\mathrm{H}_{2} \mathrm{O}$ ) and then left the mixed sample for $24 \mathrm{hrs}$ at the room temperature. After that the activated charcoal samples were filtrated and oven dried at $110{ }^{\circ} \mathrm{C}$ for 3 hrs. All of the activated charcoal samples were pyrolysed at $600{ }^{0} \mathrm{C}$ for $1 \mathrm{hr}$ in electric muffle furnace and then let it cool down to room temperature. The activated carbon samples were leached with distillation water many times until achieved a neutral $\mathrm{pH}$. Finally, the activated carbon samples were dried in electric oven at $110{ }^{\circ} \mathrm{C}$ for $3 \mathrm{hrs}$ and stored in a desiccant for use in further experiments.

Surface morphology and characteristics. Surface morphology of the activated carbon was characterized by scanning electron microscopy (SEM, JSM-6335F: JEOL, Japan). The activated carbon surface characteristics investigation was carried out by using the surface area $\&$ pore size analyzer by gas sorption (Autosorb 1MP: Quantachrome, USA) and operated under nitrogen gas condition at low temperature.

Proximate analysis of activated carbon. The proximate analysis of the $\mathrm{AC}$ which derived from tamarind pod was carried out according to ASTM D3173-95 (for moisture analysis), ASTM D317595 (for volatile matter analysis), ASTM D3174-95 (for ash analysis), and fixed carbon (100- ash \% - volatile matter \%). The apparent density of the AC sample was obtained by weighting $5 \mathrm{~g}$ of the activated carbon and transferring it into a $10 \mathrm{~mL}$ graduated cylinder. The cylinder was tamping with a rubber pad while activated carbon was being added until the entire original sample was transferred to the cylinder. Tamping was continued for 5 minutes until there was no further settling produced. The volume was recorded and the apparent density was calculated on the dry basis:

$$
\text { Apparent density }=\frac{\text { weight of the sample }(\mathrm{g})}{\text { volume of the sample (1) }}
$$

All the experiments were carried out in triplicate and averages were presented. The results were compared with commercial activated carbon in local market.

Iodine value and phenol adsorption of the activated carbon. Iodine adsorption form liquid phase is considered a simple and quick test for evaluation the surface area of the activated carbons associated with pores larger than $1 \mathrm{~nm}$. The iodine value (defined as the amount of iodine adsorbed per gram of activated carbon at an equilibrium concentration of $0.02 \mathrm{~N}$ ) was measured according to the procedure established by the ASTM D4607-94. Phenol adsorption on the AC was studied by the standard method AWWA B600-86. The residual filtrated phenol concentration was determined by using UV-Visible spectrophotometer (UV-1700: Simadzu, Japan). The adsorbed phenol was calculated from percent of residual filtrate phenol. Each experiment was carried out in triplicate under identical conditions.

Acetic acid adsorption characteristics. The acetic acid adsorption (in batch experiments) on the AC was studied as follows; The AC was dried at a temperature of $110-120{ }^{\circ} \mathrm{C}$ for one hour, then leave to cool. Weighing approximately $2 \pm 0.01$ grams of the AC into seven Erlenmeyer flasks. Different acetic acid concentrations: 0.5, 0.4, 0.2, 0.1, 0.04 and $0.02 \mathrm{M}$ (volume of $100 \mathrm{ml}$ ) was added into each flask and covered. All samples were shaken for $2 \mathrm{hrs}$ in an orbital shaker at room 
temperature. Then all the samples were filtered through Whatman No.1 filter paper. The filtrated solution was titrated with $10.0 \mathrm{~mL}$ of $0.3 \mathrm{M}$ sodium hydroxide (the actual concentration was determined by potassium phthalate standard solution) by using phenolphthalein as indicator. The obtained data was used to create graphs according to the Langmuir isotherm and the Freundlich isotherm.

\section{Results and Discussion}

Surface morphology and characteristics. The AC in this research was prepared from sweet and sour tamarind (Tamarindus indica L.) pods damaged by mold by using the homemade kiln in pyrolysis process. Most of molds found in tamarind pods are group of bacteria such as Phomopsis sp., Aspergillus sp., and Aspergillus niger [14]. In the AC production, the mold damaged tamarind pods (Figure1(a)) was carbonized at $400{ }^{0} \mathrm{C}$ for 4 hrs to give the tamarind pod charcoal (Fig. 1(b)). Then it was pulverized by ball mill machine to produce a small granular and sieved to mesh size 8-14. After that the granular charcoal (Fig.1(c)) was activated by using chemical and thermal at $600{ }^{0} \mathrm{C}$ for $2 \mathrm{hrs}$ to give the activated carbon as in the Fig. 1(d).

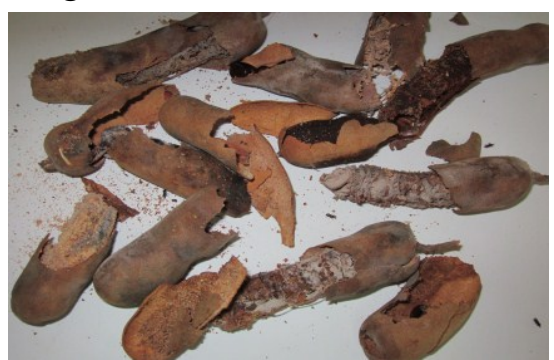

(a)

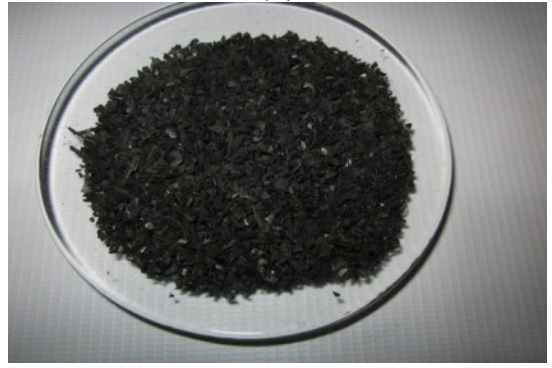

(c)

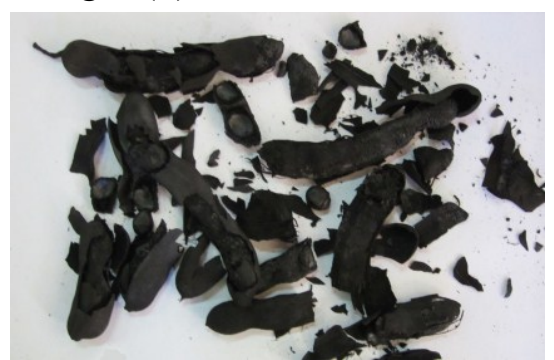

(b)

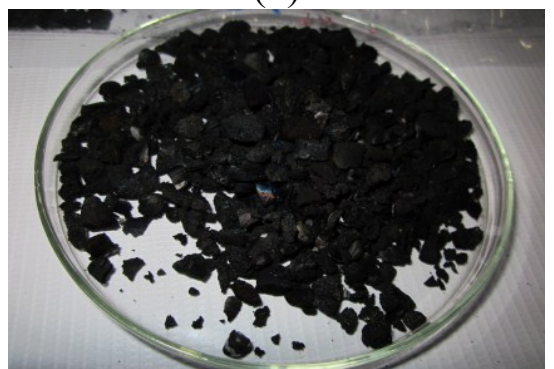

(d)

Fig. 1 Images of (a) the moldy damaged tamarind pods (b) the tamarind pod charcoal (c) the granular charcoal and (d) the granular activated carbon.

Surface morphology of the AC was characterized by SEM technique showed in Fig. 2. From the photographs, the AC derived from the tamarind pod (activation by $\mathrm{H}_{3} \mathrm{PO}_{4}$ ) showed open microporous structure and many holes on the carbon surface with broken edges (Fig.2 (a)-(b)). Compared with the commercial activated carbon (derived from coconut shell), it showed cracking hole between the carbon surface and has dense microstructure (Fig.2(c) which is different from the AC derived from the tamarind pods.

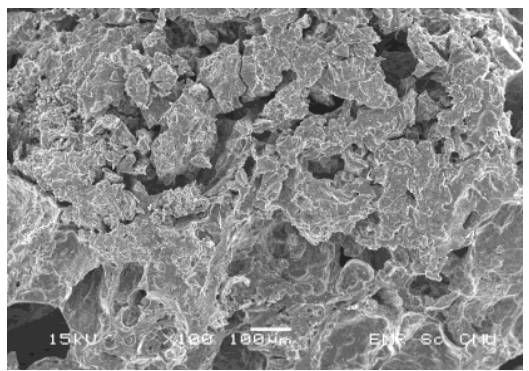

(a)

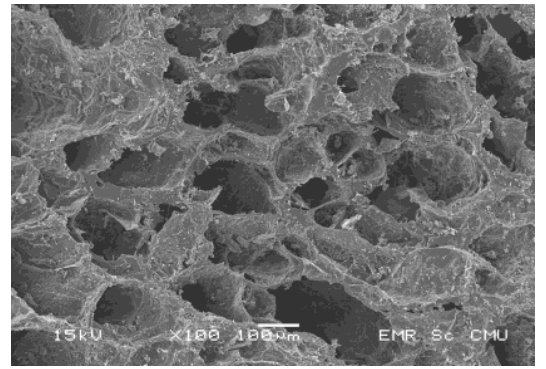

(b)

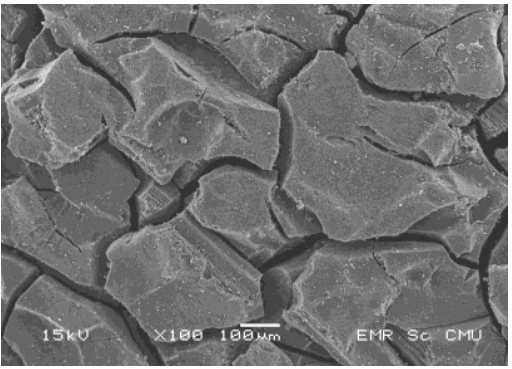

(c)

Fig. 2 SEM images of (a) microstructure of the AC derived from the tamarind pod (b) open microporous structure and many holes on the carbon surface and (c) the surface of commercial activated carbon (derived from coconut shell). 
From BET surface area analysis of the AC derived from the tamarind pod which using $\mathrm{H}_{3} \mathrm{PO}_{4}$ as the activation chemical, the results showed in table 1 .

Table 1 BET surface area of activated samples

\begin{tabular}{|l|c|c|c|c|}
\hline \multirow{2}{*}{ The AC material from } & \multicolumn{2}{|c|}{ Surface analysis of sample } & \multicolumn{2}{c|}{ Porosity analysis of sample } \\
\cline { 2 - 5 } & $\begin{array}{c}\text { Specific surface, } \\
\mathrm{S}_{\mathrm{t}}\left(\mathrm{m}^{2} / \mathrm{g}\right) \\
\text { BET Theory }\end{array}$ & $\begin{array}{c}\text { Surface area per } \\
\text { gram of sample } \\
\left(\mathrm{m}^{2} / \mathrm{g}\right)\end{array}$ & $\begin{array}{c}\text { Pore volume, } \\
\mathrm{V}_{\mathrm{p}}(\mathrm{cc} / \mathrm{g})\end{array}$ & $\begin{array}{c}\text { Average pore } \\
\text { size }(\AA)\end{array}$ \\
\hline $\begin{array}{l}\text { sweet tamarind pod } \\
\text { with } \mathrm{H}_{3} \mathrm{PO}_{4} \text { activation }\end{array}$ & 851.58 & 6202.33 & 2.24 & 52.53 \\
\hline $\begin{array}{l}\text { sour tamarind pod } \\
\text { with } \mathrm{H}_{3} \mathrm{PO}_{4} \text { activation }\end{array}$ & 910.31 & 6644.59 & 2.32 & 50.90 \\
\hline
\end{tabular}

From the table, the AC sample has surface area as $851-910 \mathrm{~m}^{2} \mathrm{~g}^{-1}$ (BET Theory) and surface area per gram of samples equal $6202.33 \mathrm{~m}^{2} \cdot \mathrm{g}^{-1}$. The results from porosity analysis found that it has porosity in the range of $2.24 \mathrm{cc} \mathrm{g}^{-1}$ and average pore radius in the range of $52.53 \AA$. While the commercial activated carbons (used for filtration) which are sold in the local market generally have specific surface area of approximately $1100 \mathrm{~m}^{2} \mathrm{~g}^{-1}$ (BET Theory). Thus the AC from tamarind pod which produced in this study has a surface area close to the commercial grade activated carbon.

Proximate analysis of activated carbon. The data on proximate analysis of the AC derived from sweet tamarind pod are present in table 2 .

Table 2 Proximate analysis of the AC derived from sweet and sour tamarind pod

\begin{tabular}{|c|c|c|}
\hline \multirow{2}{*}{ Proximate analysis } & \multicolumn{2}{|c|}{ The activated carbon derived from } \\
\cline { 2 - 3 } & Sweet tamarind pod & Sour tamarind pod \\
\hline Moisture (\% wt) & 7.54 & 6.81 \\
\hline Ash $(\% \mathrm{wt})$ & 6.58 & 7.31 \\
\hline Volatile matter $(\% \mathrm{wt})$ & 38.26 & 40.12 \\
\hline Fixed carbon $(\% \mathrm{wt})$ & 55.16 & 52.57 \\
\hline
\end{tabular}

The apparent density of the AC is about $0.4528 \mathrm{~g} \mathrm{~cm}^{-3}$ which in the range of the Thai industrial standard institute (900-2547) which not allows the apparent density lower than $0.20 \mathrm{~g} \mathrm{~cm}^{-3}$ and the moisture higher than $8 \%$. Thus, the prepared AC by using this process produces the AC which has quality under acceptable of the Thai industrial standard for commercial. In addition the production cost of the $\mathrm{AC}$ in this process is lower than 145 baths per kilogram.

Iodine value and phenol adsorption of the activated carbon. In the present study, different activating agents are expected to significantly affect the extent of activation the charcoal derived from sweet tamarind and sour tamarind. The effect of different activating agents $\left(\mathrm{H}_{3} \mathrm{PO}_{4}, \mathrm{KOH}\right.$, $\mathrm{ZnCl}_{2}$, and $\mathrm{H}_{2} \mathrm{O}$ ) on the iodine value (iodine number) and phenol adsorption were evaluated and compared as shown in table 3 .

Table 3 The effect of chemical activation agents to iodine adsorption and phenol adsorption

\begin{tabular}{|c|c|c|c|c|}
\hline \multirow{2}{*}{$\begin{array}{c}\text { Chemical } \\
\text { activation } \\
\text { agent }\end{array}$} & \multicolumn{2}{|c|}{ Sweet tamarind pod } & \multicolumn{2}{|c|}{ Sour tamarind pod } \\
\hline & $\begin{array}{c}\text { Iodine adsorption } \\
(\mathrm{mg} / \mathrm{g})\end{array}$ & $\begin{array}{c}\text { Phenol adsorption } \\
(\%)\end{array}$ & $\begin{array}{c}\text { Iodine adsorption } \\
(\mathrm{mg} / \mathrm{g})\end{array}$ & $\begin{array}{c}\text { Phenol adsorption } \\
(\%)\end{array}$ \\
\hline $\mathrm{H}_{3} \mathrm{PO}_{4}$ & 641.1 & 83.1 & 654.8 & 81.5 \\
\hline $\mathrm{KOH}$ & 625.6 & 65.6 & 633.5 & 61.7 \\
\hline $\mathrm{ZnCl}_{2}$ & 613.9 & 68.2 & 618.4 & 67.8 \\
\hline $\mathrm{H}_{2} \mathrm{O}$ & 630.7 & 72.4 & 625.1 & 70.5 \\
\hline
\end{tabular}

The results show that the activation with $\mathrm{H}_{3} \mathrm{PO}_{4}$ gives the highest iodine adsorption value and phenol adsorption of the $\mathrm{AC}$ which derived from both of sweet tamarind and sour tamarind. For the sweet tamarind, activation with only $\mathrm{H}_{2} \mathrm{O}$ can produces the $\mathrm{AC}$ with iodine adsorption value and phenol adsorption higher than the activation with $\mathrm{KOH}$ and $\mathrm{ZnCl}_{2}$. The iodine adsorption values in this experiment are higher than $613 \mathrm{mg} / \mathrm{g}$ and the phenol adsorptions are higher than $70 \%$ that is a characteristic of the AC derived from tamarind pod. 
Acetic acid adsorption characteristics. The performance of the $\mathrm{AC}$ for adsorption can be obtained from plotting graph according to Langmuir and Freundlich adsorption isotherms. The Langmuir isotherm linear equation derived a relationship for the amount of solute adsorbed per weight of adsorbent $\left(\mathrm{X} / \mathrm{m}\right.$ which represent by $\left.\mathrm{q}_{\mathrm{e}}\right)$ and the remaining concentrations in the solution $\left(\mathrm{C}_{\mathrm{e}}\right)$ at equilibrium [3,7-8]. These are based on some reasonable assumptions: a uniform surface, a single layer of adsorbed material, and constant temperature. Langmuir isotherm assumes that the number of adsorption site is fixed and that adsorption is reversible. The Langmuir equation in the adsorption of solute on adsorbent surface was linearized as follows:

$$
\frac{\mathrm{C}_{\mathrm{e}}}{\mathrm{q}_{\mathrm{e}}}=\frac{1}{\mathrm{kN}_{\mathrm{m}}}+\frac{\mathrm{C}_{\mathrm{e}}}{\mathrm{N}_{\mathrm{m}}}
$$

From the Langmuir isotherm, the relationship between specific surface area of the adsorbent (A) and maximum moles of solute per unit mass of adsorbent $\left(\mathrm{N}_{\mathrm{m}}\right)$ shown in equation (3). Whereas $\mathrm{N}_{\mathrm{o}}$ is Avogadro constant and $\delta$ is the area of acetic acid is adsorbed on the surface of the adsorbent equal $21 \AA \AA$.

$$
\mathrm{A}=\mathrm{N}_{\mathrm{m}} \mathrm{N}_{\mathrm{o}} \delta \times 10^{-20} \mathrm{~m}^{2}
$$

Freundlich isotherm is one of the most popular empirical equation which is used to express the mathematic relationship between the quantity of impurity remaining in solution versus the quantity adsorbed. The Freundlich equation was linearized as follows:

$$
\log \left(\mathrm{q}_{\mathrm{e}}\right)=\log \mathrm{k}+\frac{1}{\mathrm{n}} \log \mathrm{C}_{\mathrm{e}}
$$

Plotting values of $\mathrm{X} / \mathrm{m}$ (represent by $\mathrm{q}_{\mathrm{e}}$ ) vs. $\mathrm{C}_{\mathrm{e}}$ on $\log -\log$ paper, the isotherm is obtained. The interception of the graph indicates $\log \mathrm{k}$ and the slope of the line indicates $1 / \mathrm{n}$. The $\mathrm{k}$ and $\mathrm{n}$ are constant value of Freundlich isotherm. In this present study, adsorption of acetic acid (organic solute) on the AC derived from the sweet tamarind was studied. The plotting graph according to the Langmuir equation and the Freundlich equation was exhibited as Fig. 3 and Fig.4.

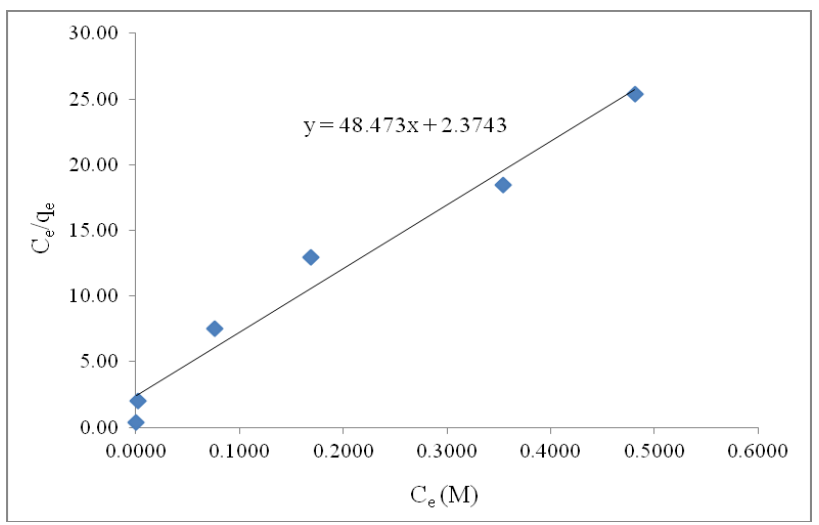

Fig. 3 The plotting graph according to the Langmuir equation of acetic acid adsorption.

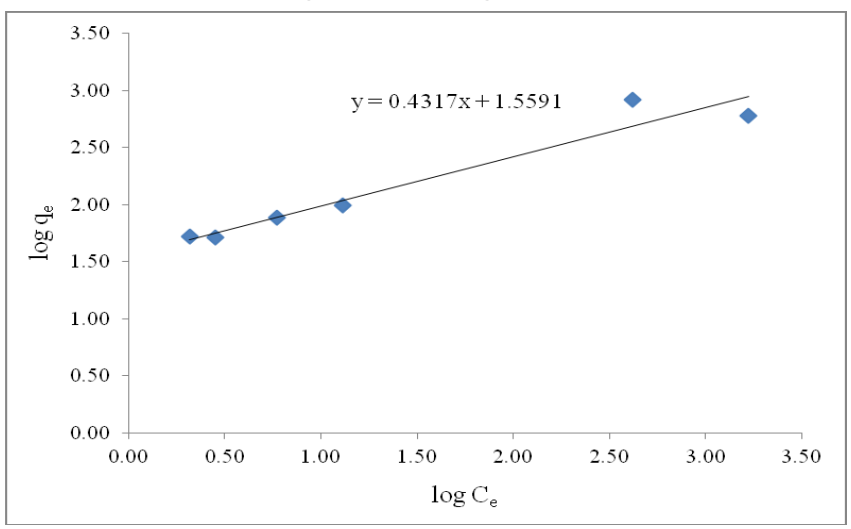

Fig. 4 The plotting graph according to the Freundlich equation of acetic acid adsorption.

The results of acetic acid adsorption on the AC according to the Langmuir linear equation shown that the $\mathrm{N}_{\mathrm{m}}$ equal $0.0206\left(\right.$ slope $\left.=1 / \mathrm{N}_{\mathrm{m}}\right)$. The specific surface area of the AC equals $2608 \mathrm{~m}^{2}$. The graph plotted by the Freundlich equation has log k equal 1.5591 then the k constant is 36.2326. The $\mathrm{k}$ constant indicated adsorption capacity of the solute on the AC surface. The high $\mathrm{k}$ constant related to high adsorption of solute on adsorbent surface. Then there is higher acetic acid concentration adsorbed on adsorbent surface (higher of $\mathrm{X} / \mathrm{m}$ ). The value of $1 / \mathrm{n}$ indicated the strength of adsorption. From the graph, the $1 / \mathrm{n}$ value equal 0.4317 then the $\mathrm{n}$ value equal 2.3164 indicated that there is high strength of adsorption on the AC surface and show a good adsorbent characteristic [3]. 


\section{Summary}

In this study, tamarind pod damaged by mold was used for the AC production. Carbonization of the tamarind pod was carried out by using the folk wisdom kiln size of $200 \mathrm{~L}$ in carbonization at $400{ }^{\circ} \mathrm{C}$ for $4 \mathrm{hrs}$. Then the activation process was done by using chemicals and thermal activation at $600{ }^{0} \mathrm{C}$ for $2 \mathrm{hrs}$. The $\mathrm{H}_{3} \mathrm{PO}_{4}$ showed higher efficiency for activation than others chemical. The produced AC has apparent density of $0.4528 \mathrm{~g} / \mathrm{cm}^{3}$, specific surface area higher than $851 \mathrm{~m}^{2} / \mathrm{g}$, pore volume of $2.24-2.32 \mathrm{~cm}^{3} / \mathrm{g}$, and average pore radius of $50.90-52.53 \AA$. It has iodine number more than $613 \mathrm{mg} / \mathrm{g}$ and phenols adsorption approximately 61-83\%. From acetic acid adsorption investigated by the Langmuir isotherm and the Freundlich isotherm showed monolayer adsorption isotherm and the activated carbon can adsorbs the acetic acid well and strength. Therefore the AC which produced by using tamarind pod and activation at the optimal condition can be applied for commercial material utilization next.

\section{Acknowledgement}

This work was subsidized by budgets of Phetchabun Rajabhat University which considered by the National Research Council of Thailand. Thank also to Faculty of Science and Technology, Phetchabun Rajabhat University for laboratory instruments support and facilitation in this study.

\section{References}

[1] A. A. M. Daifullah, B. S. Girgis, and H. M. H. Gad, Utilization of agro-residues (risk husk) in small waste water treatment plans, Mater. Lett. 57 (2003) 1723-1731.

[2] A. EI-Hendawy, S. E. Samra, and B. S. Girgis, Adsorption characteristics of activated carbons obtain from corncobs, Colloids. Surf A: Physicochemical and Engineering Aspects. 180 (2001) 209221.

[3] A. Mohammad-Khah, R. Ansari, Activated charcoal: preparation, characterization and applications: A review article. Inter. J. Chem. Tech. Res. 1 (2009) 859-864.

[4] A. EI-Hendawy, Influence of $\mathrm{HNO}_{3}$ oxidation on the structured and adsorptive properties of corncob activated carbon, Carbon. 41 (2003) 713-722.

[5] D. L. Raymond, Water Quality \& Treatment, McGraw Hill Company. New Jersey, 1999.

[6] A. O. Eremina, V. V. Golovina, M. Y. Ugal, and A. V. Ruckovskii, Activated Carbons From Waste Wood in Wastewater Treatment To Remove Surfactants. Russian J. Appl. Chem. 77(5) (2003) 775-778.

[7] R. Bansal, J. Donnet, F. Stoeckli, Active Carbon. Marcel Dekker Inc., New York, 1988.

[8] T. Wigmans, Industrial aspects of production and use of activated carbons. Carbon. 27(1) (1989) $13-22$.

[9] M. Ahmedna, S. J. Clarke, R. M. Rao, W. E. Marshall, M. M. Johns, Use of filtration and buffers in raw sugar color measurements, J. Sci. Food. Agric. 75 (1997) 109-116.

[10] K. Kairvelu, K. Thamaraiselvi, C. Namazivayam, Removal of heavy metals from industrial wastewaters by adsorption onto activated carbon prepared from an agricultural solid waste. Bioresour. Technol., 76(1) (2001) 63-65.

[11] A. Amaya, N. Medero, N. Tancredi, H. Silva, C. Deiana, Activated carbon from biomass materials. Biores. Technol. 98 (2007) 1635-1641.

[12] O. Ioannidou, A. Zabaniotou, Agricultural residues as precursors for activated carbon production; A review, Renew. Sustain. 11 (2007) 1966-2005.

[13] P. Sugumaran, V. P. Susan, P. Ravichandran, and S. Seshadri, Production and characterization of activated carbon from banana empty fruit bunch and Delonix regia fruit pod. J. Sustain Ener \& Env. 3 (2012) 125-132.

[14] B. Sisuvoramas, S. Aiumsamang, T. Piamalung, S. Sansenya, and L. Sripanom, DNA Barcodes for cultivar identification of Thailand Tamarindus indica L. International conference on Science and Technology. RMUTT. (2015) 